\title{
Lessons from COVID-19 in Disaster Preparedness: An Examination of Kenya's Education Sector's Disaster Response and Management Framework
}

\author{
Lucy A. Wakiaga \\ ORCID iD: https://orcid.org/0000-0001-8440-064X
}

\section{Abstract}

On 30 January 2020, the World Health Organization declared the coronavirus disease of 2019 (COVID-19). After reporting its first COVID-19 case on 12th March, 2020, Kenya closed down all its learning institutions on 15th March, 2020. Subsequently, the Ministry of Education (MoE) developed the Kenya basic education COVID-19 emergency plan to guide the response and management of COVID-19 pandemic in schools. In spite of this plan, schools in Kenya remained closed for the next six months, with devastating effects on the academic, physical, and psychosocial wellbeing of many learners. In addition, COVID-19 has continued to spread within learning institutions even after re-opening on 6th October, 2020. The purpose of this study was to examine the capacity of Kenya's education sector in preventing, responding to and managing disease pandemics, such as the COVID-19. A desk review included the analysis of key national and education sector documents to determine how disease pandemics are categorised within Kenya's education sector; the elements of Kenya's education sector disease pandemic response and management framework; the capacity levels of the Kenyan MoE's disaster response and management (DRM) framework in responding to the COVID-19 pandemic; and recommendations to reinforce or redesign the MoE's current DRM framework. This study was anchored on Wenger's (2017) Prevent-Prepare-Respond-Recover framework which emphasises the aspects resilience and adaptability as key to an organisation's ability to rise from a disaster, rebuild and transform itself for posterity. The 
findings indicate that the element of 'whole system planning' with regards to DRM was strongly evident in several of the education sector documents, but challenges still persist in the aspects of anticipation, avoidance, accommodation, response, and recovery. Thus, the measures put in place to address disease pandemics appear to restore the status quo rather than enhance the education sector's resilience and adaptability. Therefore, it was recommended that the MoE should place emphasis on whole system renewal and provide the requisite resources in order to strengthen its DRM framework; consequently, creating a transformational DRM system.

Keywords: COVID-19, education, disaster, disease, pandemic, preparedness, Kenya

\section{Introduction}

Disasters and disaster preparedness are concepts that have always been with us. Preparedness involves elements of planning, namely: (1) advance warning of a population; (2) stockpiling of needed resources; (3) establishment of priorities relative to what should be done; and (4) evacuation of people to a place of safety (Quarantelli 1985). A disaster can be defined as a sudden occurrence that causes catastrophic loss of life and/or physical destruction (Substance Abuse and Mental Health Services Administration [SAMHSA] 2020). A disaster disrupts the functioning and normal conditions of existence of a community by causing human, material, economic, or even environment losses in a manner that is beyond the capacity of the community to manage it using its own resources (International Federation of the Red Cross and Red Crescent [IFRC] 2021; World Health Organization/ European Hematology Association [WHO/ EHA] 2002). A community that lacks appropriate and sufficient resources is vulnerable. Thus, it is unable to cope when a hazard strikes, resulting in disaster.

A distinction is made between an 'accident/ emergency' and a 'disaster/ catastrophe'. An accident/emergency is smaller in scale, confined to a locality and can be handled by local resources and personnel (Quarantelli 1985). However, a disaster or catastrophe is larger in scope. It is a natural or manmade incident that causes extensive damage beyond a locality and severely affects the population, infrastructure, environment, economy, national morale, and/or government functions (United States Department of 


\section{Lucy A. Wakiaga}

Homeland Security [USDHS] 2008). Examples of natural disasters include earthquakes, tornadoes, severe storms, tropical storms, hurricanes, floods, wildfires, drought (SAMSHA 2020). Man-made disasters include chemical spills, bombs, explosions, terrorist attacks (Burling \& Hyle 1997). A disease outbreak (natural or manmade) can also be viewed as a disaster, especially when it morphs from a hazard to an epidemic and eventually to a pandemic. As a pandemic, the epidemic occurs simultaneously across communities and over very wide areas, crossing international boundaries and affecting large numbers of people (Kelman 2020; Last 2001). Major pandemics since 1900 include: Spanish Influenza (1918-1919); Asian Influenza (1957-1958); Hong Kong Influenza (1968-1970); Human Immunodeficiency Virus (HIV)/ Acquired Immuno-Deficiency Syndrome (AIDS) (1981-Present); Severe Acute Respiratory Syndrome (SARS) (2002-2003); Swine Influenza (20092010); Ebola (2014-2016); Middle East Respiratory Syndrome (MERS) (2015-present); and Corona Virus Disease-2019 (COVID-19) (2019present) (LePan 2020). These diseases are categorized as pandemics, and consequently as disasters, because of their transnational spread that has resulted in millions of deaths across the globe. For instance, the Ebola outbreak in 2014 caused 10,6000 deaths in Guinea, Sierra Leonne, and Liberia in West Africa (Perry \& Sayndee 2016). Currently, the world is dealing with the COVID-19 pandemic. COVID-19 is caused by the Severe Acute Respiratory Syndrome Coronavirus-2 (SARS-CoV-2). COVID-19 cases were first reported from a wholesale seafood market in Wuhan, China in December 2019 (World Health Organization [WHO] 2020a). COVID-19 is a pathogenic viral infection and is highly transmissible across humans, mainly through the nose or mouth (Shereen et al. 2020). This rapid human to human transfer has led to a global spread of the virus in a relatively short period of time. According to statistics provided by John Hopkins University, the virus has killed more than 4.2 million and infected more than 200 million around the globe since its outbreak in December 2019 to August 6, 2021 (BBC News 2021).

Globally, the impact of the COVID-19 pandemic has been severe, regardless of the socio-economic status of countries. Both developed and developing countries continue to have their share of socio-economic challenges as a result of direct or indirect impact of the pandemic. Various sectors of the economy have been disrupted, mostly in negative trajectories. Containment efforts such as social distancing, self-isolation and travel 
restrictions have resulted in a reduced workforce across all economic sectors resulting in huge job losses (Nicola et al. 2020). In addition, many countries are experiencing a recession due to value chain disruptions and lower international demand for goods, for example, South Africa, India, Mexico, France and Italy (Cantore et al. 2020). This COVID-19 disruption has not spared the education sector. Schools, because of their co-existence within communities, are susceptible to disasters, including the COVID-19 pandemic. With the rapid spread of the virus, many schools around the globe have had to either partially or totally shut down their schools. The United Nations Educational, Scientific, and Cultural Organization (UNESCO) estimated that as of mid-April 2020, over 1.5 billion learners $-91 \%$ of the world's school population - were affected, consequently widening the inequality gap in accessing educational opportunity (UNESCO 2020). The Human Rights Watch (2020) echoed the same sentiments. Between April and August 2020, it conducted a study across selected Africa countries and the results showed that school closures had exacerbated previously existing inequalities, with at-risk learners being the most affected since there had been little to no learning taking place in schools (Human Rights Watch 2020). The situation is similar globally, with experiences of learning loss and widening of the gap between the high and low achieving students (Soland et al. 2020). The effect of shutting down schools goes beyond learning. It disrupts essential services offered to children and communities, interferes with the work schedules of parents, and predisposes women and girls to violence (United Nations [UN] 2020). The impact of the pandemic on the economy has a spill over effect on education. As public revenues decline, so do budgets for schools (Schleicher 2020).

However, positive effects from the COVID-19 pandemic have also been noted in the education sector. Innovative approaches have emerged in attempts to support continuity of learning, for instance, distance learning solutions, the use of radio and television and take-home packages (UN 2020). Some countries have introduced measures to provide financial relief to the education sector. Examples of these include: The Higher Education Relief Package, launched in April 2020 by the Australian government; the Canada Emergency Student Benefit announced in April 2020; support packages for tertiary students announced by the New Zealand government in April 2020; distance learning support measures announced by the Italian government in March 2020; and England's (United Kingdom) financial support for schools 


\section{Lucy A. Wakiaga}

launched in April 2020 (Schleicher 2020). Although these are helpful interventions, in the global context, their support has been insufficient.

Global trends in reacting to the spread and containment of the virus calls into question the issue of pandemic preparedness within and across countries. As the pandemic continued to spread, there were concerns that developing countries would be unable to cope and would face social, economic and health crises due to their underdeveloped healthcare systems and lack of social protection (Bruckner \& Mollerus 2020; United Nations Development Programme [UNDP] 2020). However, developed countries have bore the brunt of the pandemic, if not exceedingly more than some developing countries such as in the African continent. The number of cases and deaths in developed countries exposed their lack of preparedness in terms of technical capability in understanding the virus, its asymptomatic phase capability and ease of transmission (Freed et al. 2020). In the education sector across the globe, the ravages of the COVID-19 pandemic have exposed its the soft underbelly. In many countries, the response to the onset of COVID-19 was the immediate shutdown of schools. This begs the question of the levels of disaster preparedness in schools, especially with regards to handling of pandemics.

An examination of literature indicates that there are two main approaches to handling pandemics: pharmaceutical and non-pharmaceutical interventions. Pharmaceutical interventions involve use of medication, such as vaccines; non-pharmaceutical interventions are the contrary. A common non-pharmaceutical approach to handling pandemics in schools is the school closure policy (Cauchemez et al. 2009; Center for Disease Control 2017). Proponents of this approach argue that it reduces the total number of cases; slows the spread of the epidemic allowing more time for production of a vaccine; and reduces stress on the healthcare systems due to the social distancing resulting from children staying at home (Cauchemez et al. 2009). A study on social distancing conducted on a small community in the United States showed that closing schools reduced the attack rate by $>90 \%$ (Glass et al. 2006). However, the study further suggested a holistic approach in the prevention and control of spread by including adults and the work environment in cases where the disease is less focused on the young and where adults are more prone to infection. However, the opponents of the school closure approach, critique the level of its resultant benefits. Some argue that there is no scientific evidence of the impact of closing schools and 
reduction pandemics (Guthrie et al. 2020). Others add that measures taken during a disease outbreak should address the disease rather than close schools (WHO 2020b).

COVID-19 has significantly affected the physical, mental and psycho-social wellbeing of children and adolescents. In a poll conducted by United Nations International Children's Emergency Fund (UNICEF) in 2020 in Latin America and the Caribbean, $27 \%$ of the participants reported feeling anxious while 15\% reported feeling depressed (UNICEF 2020). These challenges have awakened the globe to the need to have stronger response approaches to future pandemics. Policy measures aimed at prevention and control of a disease outbreak, such as COVID-19, should be more robust and move beyond a disease control lens to those that prioritize education. WHO suggests a mitigation framework, i.e., stepwise approach, consisting of personal, administrative, and environmental interventions in which there is collaboration between health authorities and schools (WHO 2020b). The children and youth should also be at the center stage of education decisions since they are the key stakeholders. Monitoring and evaluation is also crucial to gather data on disease trends that in turn inform policies within the mitigation framework. It is suggested that prevention and control of spread of epidemics needs a holistic approach in which all stakeholders in the communities are involved. WHO (2018) suggests the need for a whole-ofsociety approach in tackling $21^{\text {st }}$ Century epidemics that includes all the diverse disease drivers such as genetics and biological factors, ecology and the physical environment; human behavior and demographics; and social, political, and economic factors. Disease outbreak and spread are both medical and social. Thus, community engagement and empowerment are crucial in disease prevention and control of spread.

On the one hand, advances in science today have made vaccines to be more readily available to help contain the spread of diseases. On the other hand, the ease of global travel has made it more challenging to contain the spread a disease outbreak, as evidenced by the rapid spread of the COVID19 virus. Regardless of these challenges, pandemic preparedness plans are an important basis for response. Shearer et al. (2020) advocate for pandemic preparedness and response models and classify them into two groups: a) those aiming to inform situational awareness, and b) those aiming to understand the merits of possible interventions. In this paper, the author has opted to explore the first group. The author argues that school environments 


\section{Lucy A. Wakiaga}

are sensitive given the nature of their constituents. Therefore, models should be those that are preventive rather than reactive. In the author's view, the first group fits the preventive mould. Examples of the first group are presented in the next section.

The Global Outbreak Alert and Response Network (GOARN) asserts that prevention and control of disease transmission requires rapid and robust action, which should be anchored on the following core pillars: surveillance and contact tracing, testing, case management, infection prevention and control, epidemiological and outbreak analytics, logistics, risk communication, and community engagement (Fisher \& Carson 2020). GOARN discourages long-term lockdowns and border closures, but that their use should be short term to give time for communities to enhance their public health response.

The Center for Disease Control and Prevention (CDC) (2014), in its pandemic Preparedness and Response Framework, has developed 8 domains of planning and response activities to help manage a pandemic including: incident management, surveillance and epidemiology, laboratory, community mitigation, medical care and countermeasures, vaccine, risk communications, and state/local coordination.

The WHO identifies the continuum of pandemic phases as: interpandemic phase; alert phase; pandemic phase, transition phase, and interpandemic phase (WHO 2017). Risk assessment across these phases is done to gauge level of preparedness, response, and recovery. A detailed risk assessment should be conducted and incorporated in the emergency response management for health plans at the national and subnational levels (WHO 2017). These plans should be inclusive of all sectors of the economy and should be holistic: starting with the initial risk assessment and including: the development of short and long-term action plans; the assignment of resources to priority needs; and the provision of urgent community care and support (WHO 2017). Pandemic management processes should be clearly outlined in contingency plans and should include standard operating procedures that are appropriately disseminated, regularly exercised and updated (WHO 2017).

According to the Sendai Framework for Disaster Risk Reduction 2015-2030, states have the primary responsibility to reduce disaster risk, but they should engage other stakeholders, including local government, the private sector, and other stakeholders United Nations Office for Disaster 
Risk Reduction (UNDRR) (2021). It proposes the following 4 priorities in a disaster risk reduction: i) understanding disaster risk, ii) strengthening disaster risk governance to manage disaster risk, iii) investing in disaster risk reduction for resilience, and iv) enhancing disaster preparedness for effective response and to 'build back better' in recovery, rehabilitation and reconstruction (UNDRR 2021).

\section{Statement of the Problem}

Kenya's education sector, like other countries around the globe, has been severely impacted by the COVID-19 pandemic with little to no effective learning, taking place. This paper examines the pandemic preparedness of Kenya's education sector within the context of the situational awareness approach mentioned above and attempts to determine if the sector's approach is preventive or reactive. When WHO declared COVID-19 a global pandemic on $11^{\text {th }}$ March, 2020 (WHO 2020a), Kenya reported its first case the next day, 12th March, 2020 (Ministry of Health [MoH] (2020). Similar to approaches around the globe, the Kenya Government immediately shut down all levels of its learning institutions on $15^{\text {th }}$ March, 2020 in an effort to stem off the spread of the virus. This abrupt closure of schools disrupted learning for over 17 million Kenyan students countrywide (Jelimo 2020). Kenya's Ministry of Education (MoE) immediately prepared and released the Kenya Basic Education COVID-19 Emergency Response Plan in May 2020 (Ministry of Education [MoE] 2020). The document was fashioned after Kenya's MoH's National 2019 Novel Coronavirus Contingency (Readiness and Early Response) Plan, 2020. The latter document was developed to guide Kenya's preparedness, early detection and early response to COVID19 , with an emphasis on ensuring that pre-disaster structures, systems and capacities are in place before a disaster strike $(\mathrm{MoH} 2020)$. It is notable that in spite of the complementarity of these pandemic response plans between the Ministry of Education and the Ministry of Health, schools in Kenya were shut down for six months - March to October 2020 - when COVID-19 emerged. This begs the question of Kenya's education sector pandemic preparedness and whether its disaster response and management (DRM) framework is resilient enough to withstand disaster, especially of such magnitude as that of the COVID-19 pandemic. This paper therefore uses Wenger's (2017) modified Prevent-Prepare-Respond-Recover (PPRR) framework 


\section{Lucy A. Wakiaga}

to examine Kenya's education sector's DRM's capacity to withstand disaster. This paper argues that if a disaster response and management framework is preventive, then it has inbuilt structures that exhibit resilience and adaptability.

\section{Theory: Prevent - Prepare - Respond - Recover Framework (PPRR)}

The strength of a system is its capacity to not only absorb a disaster but to recover from it. When a disaster hits, a resilient community can continue with its normal operations or is able to rise out of a disturbance (Veil 2013). The community is endowed with resources that it can effectively deploy in order to thrive regardless of uncertainty and unpredictability in its' environment (Magis 2010). Wenger (2017) posits that resilience is coupled with adaptability. A system should have the adaptive capacity to bounce forward, thus translating resilience into a process of continuous positive change (Manyena et al. 2011). In bouncing forward, the system should be able to have improved operations after the disaster. Resilience to disaster does not mean bouncing back to status quo. Otherwise, this is considered rigidity and consequently leads to accumulation of risk. Status quo denotes stability but narrows the parameters of a system's operations because the system is shielded from exposure. Therefore, this increases a system's vulnerability in terms of awareness and response capacity (Wenger 2017). A resilient system prepares not only for the likelihood of a disaster, but also for its consequences, and therefore puts in place contingency measures to mitigate damages (National Research Council [NRC] 2012). A resilient system involves the community. There is the element of 'shared responsibility' in which the community takes charge of its own destiny, thus reducing dependency on government (United Nations Inter-Agency Secretariat of the International Strategy for Disaster Reduction [UNISDR] 2005). Resilience should elevate the system to a more effective functioning state. When studying the resilience of a system, it is important to determine whether it supports resistance, incremental or transformational change (Wenger 2017). Wenger's (2017) modified Prevent - Prepare - Response - Recover (PPRR) Framework (Table 1) is the theoretical basis for this paper. It is a framework commonly used to examine institutional disaster resilience capacity (Wenger 2017). 
Kenya's Education Sector's Disaster Response and Management

Table 1: Wenger's (2017) modified Prevent - Prepare - Response Recover (PPRR) framework

\begin{tabular}{|c|c|c|}
\hline $\begin{array}{l}\text { Original } \\
\text { PPRR } \\
\text { Framework }\end{array}$ & Modified Framework & $\begin{array}{l}\text { Comment on } \\
\text { Changes }\end{array}$ \\
\hline & Anticipate & $\begin{array}{l}\text { Added: Information } \\
\text { and assessment are } \\
\text { prerequisites of } \\
\text { mitigation }\end{array}$ \\
\hline $\begin{array}{l}\text { Prevent/ } \\
\text { Mitigate }\end{array}$ & $\begin{array}{l}\text { Avoid } \\
\text { Exposure reduction } \\
\text { [subject: engineering } \\
\text { structures] } \\
\text { [subject: incremental } \\
\text { improvement] } \\
\text { Accommodate } \\
\text { [subject: built environment] } \\
\text { [subject: ecosystem based] } \\
\text { [subject: prepare] }\end{array}$ & $\begin{array}{l}\text { Original category } \\
\text { divided to make it } \\
\text { easier to distinguish } \\
\text { 'resistance' measures } \\
\text { from those potentially } \\
\text { more transformational }\end{array}$ \\
\hline Prepare & & $\begin{array}{l}\text { Now a subset of } \\
\text { 'accommodate: } \\
\text { preparation helps } \\
\text { people live with } \\
\text { flooding, reduces } \\
\text { damage }\end{array}$ \\
\hline Respond & Respond & Unchanged \\
\hline Recover & $\begin{array}{l}\text { Recover } \\
\text { [subset: assessment and } \\
\text { funding] } \\
\text { [subset: bounce back to pre- } \\
\text { existing standards] } \\
\text { [subset: incremental } \\
\text { improvement] } \\
\text { [subset: transformational } \\
\text { change] }\end{array}$ & $\begin{array}{l}\text { Original category } \\
\text { divided to make it } \\
\text { easier to distinguish } \\
\text { status quo measures } \\
\text { from those potentially } \\
\text { more transformational }\end{array}$ \\
\hline
\end{tabular}


Wenger's (2017) modified Prevent - Prepare - Response - Recover (PPRR) Framework is grounded in the concepts of resilience and adaptability.

It has also integrated the concepts of resistance, incremental and transformational changes.

This modified version consists of six stages: Anticipate, Avoid, Exposure Reduction, Accommodate, Respond and Recover.

- The Anticipate stage involves information and assessment: two activities considered as prerequisites for disaster mitigation.

- The Avoid stage includes planning, management, zoning and enforcement. Resistance in a disaster response and management framework is proposed to exist at the Avoid stage.

- The Exposure Reduction stage has two sub-sets: Engineering structures and incremental improvement. Resistance is proposed to also exist at the engineering structures sub-set.

- The Accommodate stage has the following sub-sets: Built environment, ecosystem-based and prepare.

- The Respond stage includes information and communication systems; response capacity, capability and flexibility, and decision support systems for response management.

- The final stage is the Recover stage and has the following sub-sets: assessment and funding, bounce back to pre-existing standards, incremental improvement, and transformational change.

The stages described in Wenger's (2017) modified PPRR framework and its three types of change were used to examine the resilience and adaptability levels of Kenya's education sector's DRM framework and policies therein. The aim was to examine the type of change that characterizes Kenya's education sector's DRM framework: whether resistant, incremental 
or transformational. Additionally, the paper aimed at shedding light on whether the education sector's DRM framework is preventive or reactive especially with regards to enhancing the resilience and adaptive capacity of Kenya's schools in handling epidemics, including the COVID-19 pandemic. Therefore, contextualizing Wenger's (2017) modified PPRR framework to Kenya's education environment, the guiding research questions included:

i) How is a disaster categorized in the context of Kenya's education sector?

ii) Is there a disaster response and management (DRM) framework for Kenya's education system?

iii) What policies from Kenya's Ministry of Education (MoE) are in place to manage disasters generally?

iv) Anchored in the PPRR framework, how does the MoE's scorecard look like so far with regards to disaster response and management during the COVID-19 pandemic?

v) What recommendations can be made to reinforce or redesign the current MoE's DRM framework?

\section{Methodology}

In this study, a desk review approach was used in which an in-depth analysis of policy and practice documents on Kenya's MoE's DRM framework were examined, guided by this study's research questions. Analysis and interpretation of Kenya's MoE's DRM framework and policies were done using Wenger's (2017) modified PPRR framework to determine whether they were preventive or reactive, i.e., whether they exemplified resistance, incremental changes or transformative changes (Table 2).

The premise is that institutional resilience to disasters should avoid leaning towards supporting status quo (resistance) since this causes delays to the change process and accumulates risks for the future, rather it should incorporate transformative approaches that leads to a development trajectory (Wenger 2017). 
Lucy A. Wakiaga

Table 2: Adopted elements of Wenger's (2017) modified PPRR Framework

\begin{tabular}{|c|c|}
\hline Category & Sub-set \\
\hline Anticipate stage & $\begin{array}{l}\text { Information; assessment; decision support } \\
\text { systems; investigating/understanding } \\
\text { underlying disaster causes; adaptive learning } \\
\text { culture }\end{array}$ \\
\hline $\begin{array}{l}\text { Avoid stage } \\
\text { (Resistance) }\end{array}$ & Environment zoning and enforcement \\
\hline $\begin{array}{l}\text { Exposure Reduction } \\
\text { stage (Incremental) }\end{array}$ & Incremental improvement \\
\hline Accommodate stage & $\begin{array}{l}\text { Awareness of risks and knowledge of what to } \\
\text { do; adaptive capacity; capacity building; shared } \\
\text { responsibility; self-reliance, safety } \\
\text { behavioral/cultural change; reducing } \\
\text { vulnerability of disadvantaged groups; } \\
\text { institutional arrangements ; business continuity } \\
\text { planning, capacity of critical infrastructure and } \\
\text { services to function in disasters; redundancy; } \\
\text { substitutability; multi-hazard disaster } \\
\text { management planning; evacuation planning, } \\
\text { infrastructure and supplies; recovery planning; } \\
\text { anticipatory transformational recovery } \\
\text { planning; windows of opportunity }\end{array}$ \\
\hline Respond stage & $\begin{array}{l}\text { Information and communication systems and } \\
\text { strategies; response capacity, capability and } \\
\text { flexibility; operation centers; scenario } \\
\text { simulations and trainings; decision support } \\
\text { systems for response management; volunteer } \\
\text { recruitment, training and support }\end{array}$ \\
\hline
\end{tabular}




\begin{tabular}{|c|c|}
\hline $\begin{array}{l}\text { Recover stage } \\
\text { (Transformational) }\end{array}$ & $\begin{array}{l}\text { Assessment and funding (financial recovery; } \\
\text { post-disaster needs assessment; local } \\
\text { participation) } \\
\text { Bounce back to pre-existing standards (rapid } \\
\text { rebuild prior to standards; non-financial } \\
\text { recovery support; recovery of existing school } \\
\text { systems) } \\
\text { Incremental improvement (rebuilding or post- } \\
\text { disaster upgrade of schools; adjustment of } \\
\text { existing schools; diversification) } \\
\text { Transformational change (relocation; } \\
\text { alternative approaches to teaching and learning; } \\
\text { recovery targeting long term improvements for } \\
\text { the most vulnerable; 'build back better' aimed } \\
\text { at increasing chances of a stronger recovery } \\
\text { after a disaster. }\end{array}$ \\
\hline
\end{tabular}

\section{Results}

This section presents findings from desk review of policy and practice documents on Kenya's MoE's DRM framework. The findings are presented according to the study's research questions.

\section{Research Question One: How is a disaster categorized in the context of Kenya's education sector?}

Kenya's disaster profile is mainly dominated by droughts and floods, annually affecting about 5 million and 150, 000 people, respectively (The World Bank 2019). Other disasters in Kenya have included earthquakes, volcanoes, landslides, fires, technological accidents, locust invasions, and the Covid pandemic (Government of Kenya [GoK] 2009a; Smith 2020). According to the Education Sector Disaster Management Policy document of 2017 that is quoted in $\mathrm{MoE}$ (2018: v), a disaster is 'a serious disruption of the functioning of a community or a society at any scale due to hazardous events interacting with conditions of exposure, vulnerability and capacity, leading to one or more of the following: human, material, economic and 
environmental losses and impacts'. It is notable that the policy categorizes epidemics as disasters. The National Education Sector Strategic Plan 20182022 lists disasters as 'floods, droughts, fires, insecurity, interclan clashes among others' (MoE 2019: 94). The Basic Education Act, 2013 (Parliament of Kenya 2013) does not mention the word 'disaster' explicitly but outlines the need to have physical learning environments that are of high quality for the educational and social development of learners. It is notable that the definition of the term 'disaster' in these key documents of Kenya's education sector includes both health and non-health related events, with a heavier emphasis on the latter. However, with the onset of the COVID-19 pandemic, the Ministry of Education developed the Kenya Basic Education COVID-19 Emergency Response Plan (MoE 2020) to provide a more explicit and targeted guide for the education sector on how to manage the COVID-19 pandemic, a health-related event.

\section{Research Question Two: Is there a disaster response and management (DRM) framework for Kenya's education sector?}

Kenya's education sector DRM is found in the Education Sector Disaster Management Policy 2017, commonly known as the Education in Emergencies (EiE) Policy 2017. This document is guided by the principles of disaster management as outlined in the Constitution of Kenya, 2010; Vision 2030 (Government of Kenya [GoK] 2007); the Basic Education Act, 2013; and international agreements, including the Sendai Framework for Disaster Risk Reduction 2015-2030 (MoE 2018). The EiE Policy has also borrowed from the National Emergency Response Plan (NERP) and Standard Operating Procedures (SOPs) developed in 2014 by Kenya's National Disaster Management Unit (NDMU).

\section{Research Question Three: What policies from Kenya's Ministry of Education (MoE) are in place to manage disasters in the education sector?}

The Education in Emergencies (EiE) Policy 2017 is the policy in place for managing disasters in Kenya's education sector. It has four policies to guide DRM in Kenya's education sector, including: 
i) developing a comprehensive framework to disaster management;

ii) building disaster management capacity at all levels of the education sector;

iii) building, strengthening and maintaining partnerships among stakeholders regarding disaster manage-ment in Kenya's education sector; and

iv) developing a Monitoring Evaluation Accountability and Learning framework (MEAL) for disaster management pro-grams in the education sector (MoE 2018).

It is notable that the Kenya Basic Education COVID-19 Emergency Response Plan developed in 2020 to address the COVID-19 challenge is not a policy.

\section{Research Question Four: Anchoring on Wenger's (2017) modified PPRR framework, how does the MoE's scorecard look like so far with regards to disaster response and management during the COVID-19 pandemic?}

Ten policy documents and plans (Table 3 ) were analyzed using Wenger's 2017 modified PPRR Framework to determine whether Kenya's MoE's DRM framework exhibited characteristics of resilience and adaptability and any aspects of the three types of change mentioned above in its response and management of the COVID-19 pandemic. The documents included national policies and plans as well as those specifically related to the education sector. National documents included: The Constitution of Kenya 2010 (National Council for Law Reporting 2010), Kenya Vision 2030, the Third Medium Term Plan (TMTP) 2018-2022 (GoK 2018), the Biosafety Act 2009 (GoK 2009b), and the National Emergency Response Plan (NERP) and Standard Operating Procedures (SOPs) (GoK 2014). The rationale for analyzing the national documents is because they have been used, in varying degrees, as a basis for developing plans and policies for the education sector, including disaster risk management. The Ministry of Education documents included: The Basic Education Act 2013, the Education for Sustainable Development (ESD) Policy for the Education Sector 2017 (MoE 2017), the National Education Sector Strategic Plan (NESSP) 2018-2022, the Education Sector Disaster Management (ESDM) Policy 2017, and the Kenya Basic Education 
Lucy A. Wakiaga

COVID-19 Emergency Response Plan 2020.

Table 3: List of Kenya's key national and education policy documents and plans

\begin{tabular}{|c|c|c|}
\hline & Title of document & Author and date \\
\hline \multirow[t]{5}{*}{$\begin{array}{l}\text { National policies } \\
\text { and plans }\end{array}$} & $\begin{array}{l}\text { Constitution of Kenya } \\
2010\end{array}$ & $\begin{array}{l}\text { National Council for } \\
\text { Law Reporting (2010) }\end{array}$ \\
\hline & Kenya Vision 2030 & $\begin{array}{l}\text { Government of Kenya } \\
\text { (2018) }\end{array}$ \\
\hline & $\begin{array}{l}\text { Third Medium Term Plan } \\
\text { (TMTP) 2018-2022 }\end{array}$ & $\begin{array}{l}\text { Government of Kenya } \\
\text { (2018) }\end{array}$ \\
\hline & Biosafety Act 2009 & $\begin{array}{l}\text { Government of Kenya } \\
(2009 b)\end{array}$ \\
\hline & $\begin{array}{l}\text { National Emergency } \\
\text { Response Plan (NERP) and } \\
\text { Standard Operating } \\
\text { Procedures (SOPs) }\end{array}$ & $\begin{array}{l}\text { Government of Kenya } \\
\text { (2014) }\end{array}$ \\
\hline \multirow{3}{*}{$\begin{array}{l}\text { Kenya's Ministry } \\
\text { of Education } \\
\text { policies and plans }\end{array}$} & $\begin{array}{l}\text { The Basic Education Act } \\
2013\end{array}$ & $\begin{array}{l}\text { Parliament of Kenya } \\
\text { (2013) }\end{array}$ \\
\hline & $\begin{array}{l}\text { The Education for } \\
\text { Sustainable Development } \\
\text { (ESD) Policy for the } \\
\text { Education Sector } 2017\end{array}$ & $\begin{array}{l}\text { Ministry of Education } \\
\text { (2017) }\end{array}$ \\
\hline & $\begin{array}{l}\text { The National Education } \\
\text { Sector Strategic Plan } \\
\text { (NESSP) 2018-2022 }\end{array}$ & $\begin{array}{l}\text { Ministry of Education } \\
(2019)\end{array}$ \\
\hline
\end{tabular}


Kenya's Education Sector's Disaster Response and Management

\begin{tabular}{|l|l|l|}
\hline & $\begin{array}{l}\text { The Education Sector } \\
\text { Disaster Management } \\
\text { (ESDM) Policy 2017 }\end{array}$ & $\begin{array}{l}\text { Ministry of Education } \\
(2018)\end{array}$ \\
\hline & $\begin{array}{l}\text { The Kenya Basic } \\
\text { Education COVID-19 } \\
\text { Emergency Response Plan } \\
2020 .\end{array}$ & $\begin{array}{l}\text { Ministry of Education } \\
(2020)\end{array}$ \\
\hline
\end{tabular}

In this section, findings from these national and education sector documents are presented according to the stages adopted from Wenger's (2017) modified PPRR Framework.

See Table 4 for a summary of these stages and the related Kenya's key national and education policy documents and plans.

Table 4: List of Kenya's key national and education policy documents and plans

\begin{tabular}{|l|l|}
\hline $\begin{array}{c}\text { Stages of Wenger's } \\
\text { (2017) modified } \\
\text { PPRR framework }\end{array}$ & \multicolumn{1}{|c|}{ Related documents } \\
\hline Anticipate stage & $\begin{array}{l}\text { The Biosafety Act; the TMTP 2018-2022; the NERP } \\
\text { and SOPs 2014; the ESD Policy 2017; the Kenya } \\
\text { Basic Education COVID-19 Emergency Response } \\
\text { Plan 2020; the NESSP 2018-2022; the ESDM Policy } \\
\text { 2017 }\end{array}$ \\
\hline $\begin{array}{l}\text { Avoid stage } \\
\text { (Resistance) }\end{array}$ & $\begin{array}{l}\text { The Constitution of Kenya, 2010; the National } \\
\text { Biosafety Authority; the NERP and SOPs 2014; the } \\
\text { Kenya Basic Education COVID-19 Emergency } \\
\text { Response Plan 2020 }\end{array}$ \\
\hline
\end{tabular}




\begin{tabular}{|l|l|}
\hline $\begin{array}{l}\text { Exposure Reduction } \\
\text { stage (Incremental) }\end{array}$ & $\begin{array}{l}\text { The TMPT 2018-2022; the NERP and SOPs 2014; } \\
\text { the ESD Policy 2017; the NESSP 2018-2022; the } \\
\text { ESDM Policy 2017; the Kenya Basic Education } \\
\text { COVID-19 Emergency Response Plan 2020 }\end{array}$ \\
\hline Accommodate stage & $\begin{array}{l}\text { The TMTP 2018-2022; the NERP and SOPs 2014; } \\
\text { ESDM Policy 2017; the Kenya Basic Education } \\
\text { COVID-19 Emergency Response Plan 2020 }\end{array}$ \\
\hline Respond stage & $\begin{array}{l}\text { The Biosafety Act; the TMTP 2018-2022; the NERP } \\
\text { and SOPs 2014; the ESD Policy 2017; the NESSP } \\
\text { 2018-2022; the Kenya Basic Education COVID-19 } \\
\text { Emergency Response Plan 2020 }\end{array}$ \\
\hline $\begin{array}{l}\text { Recover stage } \\
\text { (Transformational) }\end{array}$ & $\begin{array}{l}\text { The Constitution of Kenya 2010; Kenya Vision } \\
\text { 2030; the TMTP 2018-2022; the NERP and SOPs } \\
\text { 2014; the ESDM Policy 2017; the Kenya Basic } \\
\text { Education COVID-19 Emergency Response Plan } \\
\text { 2020 }\end{array}$ \\
\hline
\end{tabular}

In the Anticipate stage, five out of ten documents exhibited aspects of 'information'. The documents included: The Biosafety Act, the TMTP 2018-2022, the NERP and SOPs 2014, the ESD Policy 2017, and the Kenya Basic Education COVID-19 Emergency Response Plan 2020. 'Information activities', also known as 'vulnerability mapping', include conducting research to monitor disasters and dissemination of findings, addressing of disaster causal factors, strengthening disaster preparedness such as setting up of national early warning and emergency community systems, and having robust monitoring and evaluation systems. By exhibiting aspects of 'information' in these five documents, it can be argued that Kenya's MoE's DRM framework seems to make provision for disaster prevention and mitigation: characteristics of incremental change. However, it is notable that none of the documents analyzed mention any methodologies that can be applied in studying disasters, including pandemics.

This aspect may pose a challenge in Kenya's MoE's capacity to effectively respond to and manage pandemics since there is lack of research 
to drive the development of innovative approaches for such endeavors.

Seven out of ten documents exhibited aspects of 'assessment', which includes risk assessment and risk management plans. The documents include the Biosafety Act, the TMTP 2018-2022, the NERP and SOPs 2014, the ESD Policy 2017, the NESSP 2018-2022, the ESDM Policy 2017, and the Kenya Basic Education COVID-19 Emergency Response Plan 2020. They made mention of risk management and risk management plans. The documents made provision for a decision support system, for instance, having an information repository for DRM that is accessible to the public (see the Biosafety Act); having county level multi-sectoral early warning, prevention and surveillance systems, and having county level multisector coordination systems to coordinate responses to disasters by government and non-governmental agencies (see the NESSP 2018 - 2022). These documents also mention adoption of an integrated and coordinated multi-level and multi-sectoral approach in DRM. The documents propose having institutional frameworks for disaster response, inter-ministerial support agreements and provision for seeking of external support in disaster response policies and plans. In the education sector documents, the Basic Education Act does not explicitly make reference to DRM in schools. However, the ESDM Policy 2017 provides for support for disaster risk reduction and EiE interventions in education and other sectors. Thus, in reference to the aspect of 'assessment', Kenya's MoE's DRM framework seems have provision for prevention and mitigation of disasters.

In the Avoid stage, none of the ten documents make explicit mention of 'environmental zoning and enforcement' in avoiding increased disaster risk. However, four of the documents give general guidance on monitoring of disaster risk. For example, Article 70 of the Constitution of Kenya, 2010 makes provision for legal redress in cases of environmental violation. The National Biosafety Authority has the mandate to issue cessation orders in cases where handling of genetically modified organisms is a danger to humans and the environment. The NERP and SOPs 2014 is tasked with developing evacuation plans and procedures and ensuring that disaster victims are placed in safe shelters. This plan was the only document analyzed that seemed to explicitly include the education sector. It outlines the role of Kenya's MoE as that of coordinating learning activities, ensuring learners are safe and victims provided with alternative shelters. The Kenya Basic Education COVID-19 Emergency Response Plan 2020 proposes having a 


\section{Lucy A. Wakiaga}

strong DRM system that ensures hotspots are identified and appropriate supports provided. Thus, the lack of explicit mention of environmental zoning and enforcement in the 10 documents increases the levels of disaster risk in Kenya's MoE's DRM framework. This situation in turn promotes status quo of the framework making it resistant to change. Consequently, the framework's effectiveness in minimized.

In the Exposure Reduction stage, six of the ten documents make mention of 'whole system planning' for DRM. The documents include: the TMPT 2018-2022, the NERP and SOPs 2014, the ESD Policy 2017, the NESSP 2018-2022, and the Kenya Basic Education COVID-19 Emergency Response Plan 2020. Examples of whole system planning include: the use of a multi-level, multi-sectoral approach in developing of a comprehensive disaster risk management strategy, i.e., engaging all levels from the national to county governments, and across the various ministries, the private sector and other relevant stakeholders in the education sector. The ESDM Policy 2017, in particular, provides a detailed narrative of strategies and activities for managing disasters in the education sector. These strategies and activities include developing a comprehensive framework for disaster management that involves setting up of Education Disaster Management Committees at all levels of education from the national, county, sub-county to learning institution levels; building disaster management capacity at all levels of education including implementing Emergency Preparedness Response Plans (EPRPs) at all levels; building, strengthening and maintaining partnerships among stakeholders regarding disaster management in Kenya's education sector; and establishing mechanisms for sustainable provision of resources to support disaster management programs in the education sector. Strategies herein include provision of a budget for disaster management programs; and mobilizing stakeholders in the quest for resources to implement these programs. Thus, in the Exposure Reduction stage, Kenya's MoE's DRM framework seems to have provision for mitigation of disasters, a characteristic of incremental change that also exemplifies a reduction of resistance.

In the Accommodate stage, four of the ten documents exhibited characteristics of 'awareness of risks' and 'knowledge of what to do'. These documents include the TMTP 2018-2022, the NERP and SOPs 2014, ESDM Policy 2017, and the Kenya Basic Education COVID-19 Emergency Response Plan 2020. They make mention of having joint efforts in developing resilience mechanisms of communities to reduce exposure and vulnerability 
to disasters, access to information on Disaster Response and Reduction (DRR) by the citizens for adequate preparedness and response during disasters, strengthening disaster risk reduction, and DRM monitoring and evaluation. For the education sector in particular, the ESDM Policy 2017 advocates for an inclusive institutional framework for DRR management in educational institutions; building capacity for preparedness and timely response and recovery in the education sector in Kenya; establishing mechanisms for effective coordination and strong collaboration and partnerships, and strengthening of monitoring and evaluation. Similarly, the Kenya Basic Education COVID-19 Emergency Response Plan 2020 advocates for conducting a comprehensive rapid needs assessment followed by a robust monitoring system to ensure interventions target the most deserving; conducting mid- term and end-term evaluations of the DRM plan; building capacity for evidence-based policy development; strengthening of the DRM system in order to identify hotspots and provide appropriate supports; building the capacity of quality assurance mechanisms and collaboration with Parent Associations (PAs) and Boards of Management (BoMs) in implementation of school-based emergency plans; and having response coordination mechanisms that are done through a multi-sectoral approach between the MoE, other ministries, and education partners. The plan also proposes that a disaster monitoring and evaluation and response mobilization strategy be developed to mobilize resources from the government, education partners and other interested parties for COVID-19 response and recovery efforts and other crises (MoE 2020).

Similar to the Anticipate and Exposure Reduction stages, the Kenya's MoE's DRM framework seems to have provision for mitigation of disasters in the Accommodate stage, thus exhibiting characteristics of an incremental change. However, it is notable that the Accommodate stage had only four out of ten documents that exhibited of 'awareness of risks' and 'knowledge of what to do'. Thus, these characteristics may need to be infused in the rest of the key documents to strengthen the capacity of the MoE's DRM framework in dealing with disasters.

In the Respond stage, six of the ten documents manifested characteristics of 'response capacity'. They include: The Biosafety Act, the TMTP 2018-2022, the NERP and SOPs 2014, the ESD Policy 2017, the NESSP 2018-2022, and the Kenya Basic Education COVID-19 Emergency Response Plan 2020. The documents have provisions for having early warn- 


\section{Lucy A. Wakiaga}

ing and emergency community systems; decision support systems; standard operating procedures for managing disasters including promoting research, DRM capacity building, and having regular drills in all public establishments. The education sector documents, in particular, have provisions for collaborative approaches, having county level multi-sectoral early warning, prevention and surveillance systems as well as coordination systems to coordinate responses to disasters; establishing resource mobilization mechanisms to provide sustainable resources to support disaster management programs. The Respond stage is categorized under transformational change and signifies characteristics of resilience and adaptability. Thus, Kenya's MoE's DRM framework seems to fit this mould.

In the Recover stage, six of the ten documents exhibited aspects of transformational change. They include: The Constitution of Kenya 2010, Kenya Vision 2030, the TMTP 2018-2022, the NERP and SOPs 2014, the ESDM Policy 2017, and the Kenya Basic Education COVID-19 Emergency Response Plan 2020. There is advocacy for protection of human life and the environment for the present and posterity; with provision for legal redress where violations occur; developing of resilience mechanism among communities; setting up DRM centers of excellent; and developing an effective multi-hazard Early Warning System (EWS) and preparedness; having DRM policy frameworks which should be available across all counties. The NDMU plan has adopted Safran's (2005) disaster management cycle. It consists of three continuous phases:

i) Transition phase - this is the emergency phase that consists of impact, and relief aid, priority and rehabilitation;

ii) Recovery phase - consists of restoration, rehabilitation and reconstruction; and

iii) Prevention phase - consists of threat, early warning, preparedness, mitigation, prevention and construction. This cycle is important to note because DRM plans in the education sector are fashioned after those of the NDMU.

However, it is notable that plans and policies for the education sector do not seem to have the 'construction' aspect. The Kenya Basic Education COVID19 Emergency Response Plan 2020 has provision for an integrated monitoring and evaluation for COVID-19 and future crises and conducting feedback 
forums, but there is no mention of construction. Similarly, the ESDM Policy 2017 has provision for a Monitoring Evaluation Accountability and Learning framework (MEAL) for disaster management programs in the education sector, but no details provided for 'construction'. The Recover stage, similar to the Respond stage, is categorized under transformational change. While Kenya's MoE's DRM framework exhibits characteristics aligned with the Recover stage, certain aspects, such as 'construction', are missing. The aspect of construction is important because it depicts the concept of 'build back better' (Wenger 2017) in which systems are re-created to withstand future disaster shocks. Such systems are thus deemed to have resilience and adaptability. Thus, the aspect of construction would be a vital addition in Kenya's MoE's DRM framework.

\section{Discussion}

It is notable that while the six stages of Wenger's (2017) modified PPRR framework appear linear, in reality, the DRM frameworks of systems are not. Thus, the findings above have shown that Kenya's MoE's DRM framework exhibits varied characteristics of Wenger's (2017) Framework. In the Anticipate, Exposure Reduction, and Accommodate stages, the Ministry of Education's DRM framework seem to lean towards prevention and mitigation. However, in the Anticipate stage, the framework seems to lack the elements of research and innovation. Shearer et al. (2020) advocate for pandemic preparedness and response models. Models can be argued to form a scientific basis for a concrete situational analysis and needs assessment, consequently resulting in more effective interventions with regards to DRM. Thus, Kenya's MoE's DRM framework can benefit from inclusion of such models. However, since DRM frameworks do not have linear responses, caution should be taken to design models that are context-specific models that respond to local needs.

The Avoid stage is where resistance can reside, i.e., normalizing the situation back to the status quo when a disaster strikes. Findings indicated that the Kenya's MoE's DRM framework lacked clarity on the aspects of environmental zoning and enforcement during disasters, though there was some mention of monitoring of disaster risk. The Kenya Basic Education COVID-19 Emergency Response Plan 2020 advocates for a strong DRM system for identifying hotspots and providing appropriate supports. Simi- 


\section{Lucy A. Wakiaga}

larly, Fisher and Carson (2020) propose surveillance and contact tracing, and infection prevention and control as some of the core pillars for disease prevention and control. Schools in Kenya were re-opened on $6^{\text {th }}$ October, 2020. Since then, COVID-19 infections have been reported in schools in various parts of the country (Yusuf 2020). With such developments, it is unclear whether or not Kenya's MoE is monitoring hotspots, conducting contact tracing, and engaging in environmental zoning. This seems to put into question the effectiveness of the Kenya's MoE's DRM framework in prevention and control of the spread of COVID-19 in learning institutions. Thus, the education sector seems to exhibit the characteristic of resistance, i.e., the need to go back to the opening of schools and to have learning continue, but having inadequate pandemic preparedness supports for the schools. Eliminating the pull to revert back to status quo can push the MoE's DRM framework from the level of resistance to incremental or even transformation change.

In the Exposure Reduction stage, four education sector documents analyzed had a strong mention of whole system planning for DRM. WHO (2020b) advocates for a holistic approach that involves all stakeholders in the prevention and control of pandemics. This approach seems be a strong trait of the education sector documents. It thus implies that the education sector has the potential for making incremental change; a step higher than resistance, a concept that characterizes the Avoid stage. Incremental change moves the system towards transformational change.

In the Accommodate stage, only two of the education sector's documents and two of the national documents explicitly mentioned provisions for awareness of risk and knowledge of what to do and reducing vulnerability for disadvantaged groups. For a more robust DRM framework, the Accommodate stage should build on the whole system planning in the Exposure Reduction stage. Since education sector DRM documents build on the national DRM documents, both sectors' documents may need to be revised to compliment DRM effort nationally and especially in the education sector.

Frameworks that exist in the Respond and Recover stages are considered transformational. In the Respond stage, three of the education sector's documents, had explicit provisions for a response capacity, exhibit some elements of transformational change. However, not much was mentioned regarding such aspects as scenario simulations and trainings, volunteer recruitment, training and support, and response capability and 
flexibility. The national documents with such mentions were only three. WHO (2017) advises the need to have a clearly outlined standard operating procedures that the stakeholders have access to and are regularly exercised and updated. The national and education sector documents need to be reexamined in order to strengthen these aspects.

In the Recovery stage, the DRM approaches should be those that not only provide incremental improvement, but also 'build back better', i.e., transforms the lives of the most vulnerable. Only two of the education sector documents exhibited the transformational aspect. WHO (2018) advocate for a whole-society approach in the effective management of pandemics. A whole society can be argued to be in a transformational stage if it involves all the relevant stakeholders. Thus, strengthening of the Respond and Recover stages will enhance the resilience and adaptability capacity of Kenya's MoE's DRM framework, resulting in a preventive and transformative model that can effectively and sustainably deal with the challenges of pandemics, COVID-19 included.

\section{Conclusion and Recommendations}

From the above, it can be argued that Kenya's MoE's DRM framework exhibit varied aspects of the concepts of resistance, increment, and transformation. Since, these documents that inform the DRM are developed from national documents, it can be argued that the latter also have gaps that will need revision in order to make all these policies and plans be in harmony and to respond more effectively to DRM. Currently, Kenya can be categorized to be at Level 3 of disaster emergency, in accordance with the NERP and SOPs 2014; an event that requires the mobilizing of national resources to respond and recover (such an event may be designated as a national disaster) (GoK 2014). Almost all the 47 counties have been affected by the COVID-19 pandemic, and infection is spreading across schools. Thus, Kenya's MoE, together with the relevant stakeholders, are at a crucial juncture that requires pause and deep reflection on the effectiveness of the sector's DRM framework. The aim should be to strengthen the framework's capacity, elevating it to the transformational level in order to effectively cushion schools against current and future pandemics and other disasters. Since stakeholders have been noted as key in DRM, strengthening of the framework should also be linked with health, social protection and economic 
interventions to make it holistic and to promote the realization of the aspect of 'building back better'. Most importantly, these improvement plans should be accompanied by clearly articulated budgets so that enough resources are made available.

\section{References}

BBC News 06 August 2021. Covid Map: Corona Virus Cases, Deaths, Vaccinations by Country.

https://www.bbc.com/news/world-51235105

Bruckner, M. \& R. Mollerus 01 May 2020. UN/DESA Policy Brief \#66: COVID-19 and the Least Developed Countries. United Nations Department of Economic and Social Affairs, Economic Analysis. https://www.un.org/development/desa/dpad/publication/un-desapolicy-brief-66-COVID-19-and-the-least-developed-countries/

Burling, W.K. \& A.E. Hyle 1997. Disaster Preparedness Planning: Policy and Leadership Issues. Disaster Prevention and Management 6,4: 234 - 244. https://doi.org/10.1108/09653569710179075

Cantore, N. \& F. Hartwich, A. Lavopa, K. Haverkamp, A. Laplane, N. Rodousakis 10 July 2020. Coronavirus: The Economic Impact. Policy, Research and Statistics Department, UNIDO.

https://www.unido.org/stories/coronavirus-economic-impact-10-july2020

Cauchemez, S. \& N.M. Ferguson, C. Wachtel, A. Tegnell, G. Saour, B. Duncan, A. Nicoll 2009. Closure of Schools during an Influenza Pandemic. The Lancet: Infectious Diseases 9,8 473 - 481.

https://doi.org/10.1016/S1473-3099(09)70176-8

Center for Disease Control and Prevention (CDC) 2017. Get your School Ready for Pandemic Flu.

https://www.cdc.gov/nonpharmaceutical-interventions/pdf/gr-pan-flued-set.pdf

Fisher, D.A. \& G. Carson August 2020. Back to Basics: The Outbreak Pillars. Global Outbreak Alert and Response Network (GOARN). https://extranet.who.int/goarn/content/back-basics-outbreak-responsepillars; https://doi.org/10.1016/S0140-6736(20)31760-8

Freed, J.S. \& S. Y. Kwon, E. H. Jacobs, M. Gottlieb, R. Roth 2020. Which 
Country is truly developed? COVID-19 has answered the question. Annals of Global Health 86,1: 51. http://doi.org/10.5334/aogh.2894 PMid:32477887 PMCid:PMC7243834

Glass, R.J. \& L.M. Glass, W.E. Beyeler, H.J. Min 2006. Targeted social distancing design for pandemic influenza. Emerging infectious diseases, 12(11), 1671-1681.

https://doi.org/10.3201/eid1211.060255

PMid:17283616 PMCid:PMC3372334

Government of Kenya (GoRK) 2007. Vision 2030. The popular version. http://vision2030.go.ke/inc/uploads/2018/05/Vision-2030-Popular-

Version.pdf

Government of Kenya (GoK) 2009a. National policy for disaster management in Kenya. https://www.ifrc.org/docs/idrl/1058EN.pdf

Government of Kenya (GoK) 2009b. Biosafety Act 2009. Kenya Gazette Supplement No. 10 (Acts No.2). Government Printer, Nairobi. https://www.education.go.ke/index.php/downloads/file/101-bio-safetyact-2009?start=20

Government of Kenya (GoK) 2018. Third medium term plan 2018-2022.

https://planning.go.ke/wp-content/uploads/2018/12/THIRD-

MEDIUM-TERM-PLAN-2018-2022.pdf

Government of Kenya (GoK) 2014. National emergency response plan \& standard operating procedures (SOPs). Available at:

https://disastermanagement.go.ke/downloads/

Guthrie, B.L. \& D.M. Tordoff, J. Meisner, L. Tolentino, Jiang, et al. 06 July 2020. Summary of School Re-Opening Models and Implementation Approaches During the COVID 19 Pandemic July 6, 2020.

https://www.doh.wa.gov/Portals/1/Documents/1600/coronavirus/2020

0706-SchoolsSummary.pdf

International Federation of the Red Cross and Red Crescent (IFRC) 2021. Public Awareness and Public Education for Disaster Risk Reduction. https://media.ifrc.org/ifrc/messages-disaster-prevention/

Human Rights Watch 2020. Impact of COVID-19 on Children's Education in Africa. Submission to The African Committee of Experts on the Rights and Welfare of the Child $35^{\text {th }}$ Ordinary Session 31 August -4 September 2020.

https://www.hrw.org/sites/default/files/media 2020/08/Discussion\%20 Paper\%20-\%20Covid\%20for\%20ACERWC.pdf 
Jelimo, C. 01 September 2020. Impact of COVID-19 on the Right to Education in Kenya. Right to Education.

https://www.right-to-education.org/blog/impact-COVID-19-righteducation-kenya

Kelman, L. 2020. COVID-19: What is the Disaster? Social Anthropology/ Anthropologie Sociale 28,2: 296 - 297.

https://doi.org/10.1111/1469-8676.12890

PMid:32836969 PMCid:PMC7280630

National Council for Law Reporting 2010. The Constitution of Kenya 2010. http://extwprlegs1.fao.org/docs/pdf/ken127322.pdf

Last, J.M. (ed.). 2001. A Dictionary of Epidemiology. $4^{\text {th }}$ Edition. New York: Oxford University Press.

LePan, N. 15 March 2020. A Visual History of Pandemics. World Economic Forum. https://www.weforum.org/agenda/2020/03/a-visual-history-ofpandemics

Magis, K. 2010. Community Resilience: An Indicator of Social Sustainability. Society and Natural Resources 23,5: 401 - 416. https://doi.org/10.1080/08941920903305674

Manyena, S. B. \& G. O’Brien, P. O’Keefe, J. Rose 2011. Disaster Resilience: A Bounce Back or Bounce Forward Ability? Local Environment: The International Journal of Justice and Sustainability 16,5: 417 - 424. http://dx.doi.org/10.1080/13549839.2011.583049

Ministry of Education 2017. Education for Sustainable Development Policy for the Education Sector.

https://www.education.go.ke/index.php/downloads/file/308-unescopolicy-for-education-sector-web-fa

Ministry of Education 2018. Education Sector Disaster Management Policy 2017. https://www.education.go.ke/index.php/downloads/file/641education-sector-disaster-management-policy

Ministry of Education 2019. National Education Sector Strategic Plan 2018 $-2022$.

https://www.education.go.ke/images/NESSP/NESSP-2018-2022.pdf

Ministry of Education 2020. Kenya Basic Education COVID-19 Emergency Response Plan. State Department of Early Learning and Basic Education. Available at:

https://www.education.go.ke/images/Kenya basic Education COVID -9_Emergency_Response_Plan-compressed.pdf 
Ministry of Health 2020. First Case of Coronavirus Disease Confirmed in Kenya. https://www.health.go.ke/first-case-of-coronavirus-diseaseconfirmed-in-kenya/

National Research Council (NRC) 2012. Dam and Levee Safety and Community Resilience: A Vision for |future Practice. National Research Council Committee on Integrating Dam and Levee Safety and Community Resilience. NRC, Washington, D.C., USA.

Parliament of Kenya 2013. Basic Education Act No. 14 of 2013. Available

at: http://www.parliament.go.ke/sites/default/files/2017-

05/BasicEducationActNo_14of2013.pdf

Perry, J. \& T.D. Sayndee 2016. Social Mobilization and the Ebola Virus disease in Liberia. Lanham: Hamilton Books.

Nicola, M. \& Z. Alsafi, C. Sohrabi, A. Kerwan, A. Al-Jabir, C. Iosifidis, M. Agha, R. Agha 2020. The Socio-economic Implications of the Coronavirus Pandemic (COVID-19): A Review. International Journal of Surgery 78, 185 - 193. https://doi.org/10.1016/j.ijsu.2020.04.018 PMid:32305533 PMCid:PMC7162753

Quarantelli, E.L. 1985. Organizational Behavior in Disasters and Implications for Disaster Planning. The Disaster Research Center Report Series 18. https://udspace.udel.edu/bitstream/handle/19716/1265/RS18.pdf Schleicher, A. 2020. The Impact of COVID-19 on Education Insights: Insights from Education at a Glance. OECD.

https://www.oecd.org/education/the-impact-of-COVID-19-oneducation-insights-education-at-a-glance-2020.pdf

Shearer, F.M. \& R. Moss, J. McVernon, J.V. Ross, J.M. McCaw 2020. Infectious Disease Pandemic Planning and Response: Incorporating Decision Analysis. PLoS Med 17,1: e1003018.

https://doi.org/10.1371/journal.pmed.1003018

PMid:31917786 PMCid:PMC6952100

Shereen, M. A. \& S. Khan, A. Kazmi, N. Bashir, R. Siddique 2020. COVID19 Infection: Origin, Transmission, and Characteristics of Human Coronaviruses. Journal of Advanced Research 24: 91 - 98. https://doi.org/10.1016/j.jare.2020.03.005

Smith, E. 18 May 2020. Coronavirus, Floods and Locust Swarms: Kenya is Fighting a 'Triple Whammy' of Crises. https://www.cnbc.com/2020/05/18/coronavirus-floods-and-locustskenyas-triple-whammy-of-crises.html 
Soland, J. \& M. Kuhfeld, B. Tarasawa, A. Johnson, E. Ruzek, J. Liu 27 May 2020. The Impact of COVID-19 on Student Achievement and What it May Mean for Educators. Brown Center Chalkboard.

https://www.brookings.edu/blog/brown-center-

chalkboard/2020/05/27/the-impact-of-COVID-19-on-student-

achievement-and-what-it-may-mean-for-educators/

Substance Abuse and Mental Health Services Administration (SAMHSA) 2020. Types of Disasters.

https://www.samhsa.gov/find-help/disaster-distress-helpline/disastertypes

The World Bank 2019. Kenya Disaster Risk Profile. Africa Disaster Risk Financing Initiative.

https://documents1.worldbank.org/curated/en/571741574231702074/p df/Disaster-Risk-Profile-Kenya.pdf

United Nations 2020. Education during COVID-19 and Beyond. Policy

Brief. https://www.un.org/development/desa/dspd/wpcontent/uploads/sites/22/2020/08/sg policy brief COVID-

19 and education august 2020.pdf

United Nations Development Programme (UNDP) 30 March 2020. COVID-

19: Looming Crisis in Developing Countries Threatens to Devastate Economies and Ramp up Inequality.

https://www.undp.org/content/undp/en/home/news-

centre/news/2020/COVID19_Crisis_in_developing_countries_threaten s_devastate_economies.html

United Nations Office for Disaster Risk Reduction [UNDRR] 2021. What is the Sendai Framework for Risk Reduction?

https://www.undrr.org/implementing-sendai-framework/what-sendaiframework

United Nations Educational, Scientific, and Cultural Organization (UNESCO) 2020. Responding to COVID-19 and Beyond`; The Global Education Coalition in Action.

https://unesdoc.unesco.org/ark:/48223/pf0000374364

United Nations International Children's Emergency Fund (UNICEF) 2020.

The Impact of COVID-19 on the Mental Health of Adolescents and Youth.

https://www.unicef.org/lac/en/impact-COVID-19-mental-healthadolescents-and-youth 
United Nations Inter-Agency Secretariat of the International Strategy for Disaster Reduction (UNISDR) 2005. Hyogo Framework for Action 2005 - 2015: Building the Resilience of Nations and Communities to Disasters. UNISDR, Geneva, Switzerland.

http://www.unisdr.org/files/1037 hyogoframeworkforactionenglish.pd $\underline{f}$

United States Department of Homeland Security [USDHS] 2008. National Response Framework. Chapter. 2: Response Actions, 42. Available at http://www.fema.gov/pdf/emergency/nrf/nrf-core.pdf

Veil, S.R. 2013. Resilient Communities. In Heath, R.L. (ed.): Encyclopaedia of Public Relations. Volume II. $2^{\text {nd }}$ Edition. Thousand Oaks, CA: Sage. Wenger, C. 2017. The Oak or the Reed: How Resilience Theories are Ttranslated into Disaster Management Policies. Ecology and Society 22,3: 18 .

https://doi.org/10.5751/ES-09491-220318

World Health Organization (WHO) 2017. Pandemic Influenza Risk Management: A WHO Guide to Inform and Harmonize National and International Pandemic Preparedness and Response.

https://apps.who.int/iris/bitstream/handle/10665/259893/WHO-WHE-

IHM-GIP-2017.1-eng.pdf?sequence=1\&isAllowed=y

World Health Organization (WHO) 2018. Managing Epidemics: Key Facts about Major Deadly Diseases. Geneva: World Health Organization. Licence: CC BY-NC-SA 3.0 IGO.

https://www.who.int/emergencies/diseases/managing-epidemicsinteractive.pdf

World Health Organization (WHO) 23 April 2020. Coronavirus Disease 2019 (COVID-19) - Situation Report - 94. https://www.who.int/docs/default-source/coronaviruse/situationreports/20200423-sitrep-94-COVID-19.pdf

World Health Organization (WHO) 04 September 2020. Europe Lights the Way for Schooling during the COVID-19 Pandemic and Beyond. https://www.euro.who.int/en/health-topics/Life-stages/child-andadolescent-health/news/news/2020/9/europe-lights-the-way-forschooling-during-the-covid-19-pandemic-and-beyond World Health Organization/ European Hematology Association (WHO/ EHA) 2002. Disasters and Emergencies: Definitions. https://apps.who.int/disasters/repo/7656.pdf 
Yusuf, M. 02 November 2020. Kenyan Union says COVID-19 in Schools Putting Teachers at Risk. https://www.voanews.com/africa/kenyanunion-says-COVID-19-schools-putting-teachers-risk

\author{
Dr. Lucy A. Wakiaga \\ Tangaza University College \\ Nairobi \\ Kenya \\ lwakiaga@tangaza.ac.ke
}

